\title{
Sunflower nutrition irrigated with domestic sewage treated
}

\author{
Daniel Costa Dantas'*, Ênio Farias de França e Silva', Mara Suyane Marques Dantas', \\ Gerônimo Ferreira da Silva', Mario Monteiro Rolim'
}

\author{
'Rural Federal University of Pernambuco, Recife, Brazil \\ *Corresponding author, email: dlcdantas@hotmail.com
}

\begin{abstract}
This study aimed to evaluate the nutritional status of the sunflower (Helianthus annus L.) irrigated with domestic effluents. The study was performed in a pilot sewage treatment plant, where the treatments were composed by the combination of two factors: types of water $\left(A_{1}\right.$ - effluent treated by UASB reactor; $A_{2}$ - effluent treated with digester decant and anaerobic filtering; $\mathrm{A}_{3}$ - effluent treated with anaerobic filtering; and $A_{4}$ - water supply) and irrigation depths $\left(L_{1}\right.$ - equal to the crop evapotranspiration (ETC) and $L_{2}-1.2$ ETC. The experimental design was in randomized blocks, in a $4 \times 2$ factorial scheme, with four replications. At 96 days after sowing, the leaves, capitulum, and achenes were collected for the concentration evaluation of $\mathrm{N}, \mathrm{P}, \mathrm{K}, \mathrm{Ca}$, $\mathrm{Mg}$ and $\mathrm{S}$. The analyses of variance were performed based on the concentration of the nutrients in the respective organs; when significant, they were analyzed by orthogonal contrasts. The sunflower nutritional status was influenced by the types of treatment for the domestic sewage, especially regarding $\mathrm{N}, \mathrm{Ca}$ and $\mathrm{S}$, and by the irrigation depths; the sunflower crop presented a better nutritional balance when irrigated with treated domestic effluents; with the application of the water supply only, the nutritional supply of the $P$ and $S$, is necessary.
\end{abstract}

Keywords: nutrient contents, Helianthus annuus L., water reuse

\section{Introduction}

In semiarid regions, hydric scarcity directly affects the yield of agricultural crops. Large volumes of domestic sewers are daily released in the environment, causing environmental damages (Bezerra \& Fideles Filho, 2009). The use of sewage effluents in irrigation has been an alternative to the scarcity of supply water with regard to agricultural production (Deon et al., 2010; Freitas et al., 2011).

Among the treatment processes, anaerobic processes are being widely use for presenting good efficiency, celerity, and low cost (Singh \& Prerna, 2009).

In studies on the ionic composition of treated domestic wastewater, Pereira et al. (2011) observed that more than $66 \%$ of the total concentration of macro and micronutrients are presented in the readily available form for the plants. Researches aiming to evaluate the use effect of residual wastewaters in the developmental and nutritional aspects of sunflower were conducted (Friedman et al., 2007; Lobo \& Grassi Filho, 2007; Santos Junior et al., 2011 ; Nascimento et al., 2013), in which the authors observed that with the use of such wastewaters, superior or even equivalent yields to the crop irrigated with supply water were obtained.

Evaluations of the nutritional status of the crops are currently performed aiming to improve 
the nutritional management and the respective yields, being the most used diagnostic method, based on the critical leaf nutrient content (Castamann et al., 2012).

Each type of sewage provides the obtainment of specific effluents, and these may cause different nutritional relations in the crop.

Given the foregoing, the aim of this work was to evaluate the nutritional stage of the sunflower irrigated with domestic effluents originated from different treatment methods, under two irrigation depths.

\section{Material and Methods}

The experiment was developed in the Pilot Unit of Hydro Agricultural Reuse of the Federal Rural University of Pernambuco (UFRPE),
Ibimirim, $P E$, with geographic coordinates $8^{\circ} 32^{\prime} 05^{\prime \prime}$ S, 37041'58" $\mathrm{W}$ and elevation of $408 \mathrm{~m}$. The climatic classification, according to Köppen, is BSW'h', very hot semiarid, with average annual precipitation of $454 \mathrm{~mm}$ and mean annual temperature of $24.7^{\circ} \mathrm{C}$. During the experiment, the mean temperature obtained was $26.9^{\circ} \mathrm{C}$, and accumulated precipitation of $175.2 \mathrm{~mm}$. For the determination of soil fertility, samples from the $0-0.20$ and $0.20-0.40 \mathrm{~m}$ soil layers were collected, whose values are presented in Table 1.

The soil was classified as fertile $/ \mathrm{V} \%=$ 61.9), with average cation exchange capacity at $\mathrm{pH}$ 7.0, average potential acidity, and good and average organic carbon contents for the two layers, respectively (Alvarez et al.,1999).

Table 1. Chemical characteristics of the soil collected in the experimental area

\begin{tabular}{|c|c|c|c|c|c|c|c|c|c|c|c|c|}
\hline \multirow{2}{*}{$\begin{array}{l}\text { Layer } \\
\text { (m) }\end{array}$} & \multirow{2}{*}{$\mathrm{pH}\left(\mathrm{H}_{2} \mathrm{O}\right)$} & $\mathrm{Ca}^{2+}$ & $\mathrm{Mg}^{2+}$ & $\mathrm{K}^{+}$ & $\mathrm{Na}^{+}$ & SB & $\mathrm{H}+\mathrm{Al}$ & CEC & ESP & V & \multirow{2}{*}{$\begin{array}{c}\mathrm{P} \\
\mathrm{mg} \mathrm{kg}^{-1}\end{array}$} & \multirow{2}{*}{$\begin{array}{l}\mathrm{TOC} \\
\mathrm{g} \mathrm{kg}^{-1}\end{array}$} \\
\hline & & \multicolumn{7}{|c|}{$\mathrm{cmol}_{\mathrm{c}} \mathrm{dm}^{-3}$} & \multicolumn{2}{|c|}{$\%$} & & \\
\hline $0-0.2$ & 7.1 & 2.39 & 2.30 & 0.26 & 0.36 & 5.31 & 2.90 & 8.21 & 4.38 & 64.8 & 71.41 & 2.97 \\
\hline $0.2-0.4$ & 7.0 & 1.88 & 2.20 & 0.25 & 0.38 & 4.71 & 3.26 & 7.97 & 4.77 & 61.4 & 42.34 & 1.65 \\
\hline
\end{tabular}

The experimental design was in randomized blocks, in a $4 \times 2$ factorial scheme with four replications. The factors consisted of the utilization of four water types $\left(A_{1}\right.$ - domestic sewage treated with a UASB anaerobic reactor, $A_{2}$ - domestic sewage treated with digester decant and anaerobic filtering, $A_{3}$ - domestic sewage treated with anaerobic filtering, and $A_{4}$ supply water). The second factor consisted in the utilization of different irrigation depths, $\mathrm{L}_{1}$ - equal depth to the crop evapotranspiration (ETC) and $\mathrm{L}_{2}$ - equal depth to 1.2 ETC in the cultivation of Helianthus annuus $L$.

Soil preparation consisted of the turning of the soil in the planting grooves at a $0.15 \mathrm{~m}$ depth. Direct sowing was use with the cultivar Helio 250 , in $0.25 \mathrm{~m}$ within-row and $1.0 \mathrm{~m}$ betweenrow spacings.

The experimental plot consisted in three rows of $6 \times 3 \mathrm{~m}$; the central row was selected as usable area, corresponding to 10 plants, allowing two plants from each extremity as borders.

A dripping irrigation system constituted of a polyethylene tube with $16 \mathrm{~mm}$ of nominal diameter was use, with emitters spaced $0.33 \mathrm{~m}$ and a nominal flow rate of $4 \mathrm{~L} \mathrm{~h}$. The irrigation management was performed based on the estimative of the daily reference evapotranspiration, according to the methodology of Penman-Monteith, recommended by FAO 56 (Allen et al., 2006), applying an irrigation interval of 1 day. The mean location coefficient (KLmed) was determined from the projection of the shaded area (S) of the plant at noon, according to Albuquerque et al. (2011). The crop coefficients (Kc) of 0.3, 1.15, and 1.0 were applyed for stages I, III, and IV, which correspond to the periods of 18,33 , and 18 days, respectively.

Analyses of the waters employed in irrigation were performed fortnightly, in accordance with the recommendations of the Standard Methods for the Examination of Water and Wastewater (APHA, 2005), presented in Table 2.

The plants were collected at 96 days after sowing (DAS), being fractioned into leaves with petioles, capitulum and achenes. The materials were subjected to drying in a forced airdrying oven at $65^{\circ} \mathrm{C}$, grinded in a Willey mill and quantified as to the contents of $\mathrm{N}, \mathrm{P}, \mathrm{K}, \mathrm{Ca}, \mathrm{Mg}$ and $S$, according to Bezerra Neto \& Barreto (2011). 
Table 2. Characterization of the physical-chemical parameters of the waters used in irrigation

\begin{tabular}{|c|c|c|c|c|}
\hline \multirow{2}{*}{ Parameters } & \multicolumn{4}{|c|}{ Types of waters } \\
\hline & $A_{1}-U A S B$ & $A_{2}-D D+F A$ & $A_{3}-F A$ & $\mathrm{~A}_{4}$ - supply water \\
\hline $\mathrm{pH}$ & 6.87 & 6.88 & 6.95 & 6.53 \\
\hline $\mathrm{EC}\left(\mathrm{dS} \mathrm{m}^{-1}\right)$ & 2.14 & 1.99 & 1.88 & 0.22 \\
\hline Calcium (Ca) (mg L-1) & 155.60 & 109.50 & 150.70 & 32.10 \\
\hline Magnesium (Mg) (mg L-1) & 44.70 & 62.90 & 33.80 & 20.60 \\
\hline Sodium (Na) $\left(\mathrm{mg} \mathrm{L}^{-1}\right)$ & 99.10 & 116.60 & 111.70 & 22.50 \\
\hline SAR $\left(\mathrm{mmol} \mathrm{L}^{-1}\right)^{0.5}$ & 1.80 & 2.20 & 2.14 & 0.76 \\
\hline Total nitrogen (N) (mg L-1) & 106.90 & 74.32 & 84.30 & - \\
\hline Phosphate (P) (mg L-1) & 10.30 & 8.70 & 9.40 & 0.31 \\
\hline Potassium (K) (mg L-1) & 43.60 & 42.40 & 53.60 & 13.30 \\
\hline Chloride (Cl) (mg L-1) & 171.10 & 159.00 & 186.20 & 38.30 \\
\hline Sulfate - $\left(\mathrm{SO}_{4}^{2-}\right)\left(\mathrm{mg} \mathrm{L}^{-1}\right)$ & 19.80 & 89.60 & 67.70 & 5.19 \\
\hline Water hardness - $\mathrm{CaCO}_{3}\left(\mathrm{mg} \mathrm{L}^{-1}\right)$ & 221.60 & 196.20 & 222.80 & 81.30 \\
\hline SST (mg L-1) & 61.60 & 44.30 & 114.60 & 22.40 \\
\hline $\operatorname{COD}\left(\mathrm{mg} \mathrm{L}^{-1}\right)$ & 395.50 & 384.60 & 694.90 & 10.80 \\
\hline $\mathrm{BOD}\left(\mathrm{mg} \mathrm{L}^{-1}\right)$ & 36.10 & 47.30 & 65.00 & 0.90 \\
\hline
\end{tabular}

The data were evaluated through analysis of variance by the "F" test. When a significance was verified $(p<0,05)$ they were subjected to the following orthogonal contrasts: $1\left(-A_{1}\right.$ vs $A_{2)} ; 2\left(-A_{1}\right.$ vs $\left.A_{3}\right) ; 3\left(-A_{1}\right.$ vs $\left.A_{4}\right) ; 4\left(-A_{2}\right.$ vs $\left.A_{3}\right) ; 5$ $\left(-2 A_{2}\right.$ vs $\left.\left(A_{1}+A_{3}\right)\right) ; 6\left(-3 A_{4}\right.$ vs $\left.\left(A_{1}+A_{2}+A_{3}\right)\right) ; 7\left(-L_{1} v s\right.$ $\left.L_{2}\right)$, being analyzed by the ' $F$ ' test $(p<0.05)$. When an interaction between factors was verified, the unfolding of the studied factors was performed, using the Scott-Knott mean test $(\mathrm{p}<0.05)$ and the Sisvar software (Ferreira, 2011).

\section{Results and Discussion}

The nutritional status of the sunflower crop was influenced by the types of treatment of domestic sewage and by the irrigation depths.

In the leaves and petioles, a significant effect $(p<0,05)$ of the interaction between the types of water and irrigation depths for the nutrients $P$ and $S$ was verified, as well as an isolate effect of the types of water for the nutrients N, P, K, Ca, Mg and $S$. For the $L_{1}$ irrigation depth, it was verified that the treatments irrigated with domestic effluents presented concentrations of $P$ above those irrigated with supply water $\left(A_{4}\right)$ (Table 3$)$. This development can be attributed to the blocking of the $\mathrm{P}$ adsorption sites in the soil by the organic matter (OM), added mainly by the effluents of $A_{2}$ and $A_{3}$ types, where the carboxylic and phenolic functional groups of the organic acids bind to the hydroxyls of the $\mathrm{Fe}$ and $\mathrm{Al}$ oxides and complex the $\mathrm{Al}$ in solution (Hue, 1991).

Table 3. Nutritional content (mean and standard error) of $P$ and $S$ in the leaves of the sunflower irrigated with different water sources and irrigation depths

\begin{tabular}{|c|c|c|c|c|c|c|c|c|}
\hline \multirow{2}{*}{ Water sources } & \multicolumn{4}{|c|}{$P\left(g_{k g}^{-1}\right)$} & \multicolumn{4}{|c|}{$S\left(g_{k g}^{-1}\right)$} \\
\hline & $\mathrm{L}_{1}$ & & $\mathrm{~L}_{2}$ & & $\mathrm{~L}_{1}$ & & $\mathrm{~L}_{2}$ & \\
\hline $\mathrm{A}_{1}$ & $3.0 \pm 0.32$ & $a A$ & $2.8 \pm 0.12$ & $\mathrm{aA}$ & $7.0 \pm 0.32$ & bA & $7.2 \pm 0.29$ & $a \mathrm{~A}$ \\
\hline $\mathrm{A}_{2}$ & $3.5 \pm 0.5$ & $a A$ & $3.8 \pm 0.16$ & $a A$ & $8.6 \pm 1.29$ & $a A$ & $7.4 \pm 0.61$ & $\mathrm{aA}$ \\
\hline $\mathrm{A}_{3}$ & $4.0 \pm 0.5$ & $a A$ & $3.3 \pm 0.20$ & $\mathrm{aA}$ & $8.6 \pm 0.81$ & $a A$ & $6.9 \pm 0.33$ & $a B$ \\
\hline $\mathrm{A}_{4}$ & $1.1 \pm 0.14$ & $\mathrm{bB}$ & $2.7 \pm 0.46$ & $\mathrm{aA}$ & $2.9 \pm 0.26$ & $C A$ & $4.3 \pm 0.67$ & $\mathrm{bA}$ \\
\hline
\end{tabular}

No significant effect of the $L_{2}$ irrigation depth was verified for the content of $P$ in the leaves; however, it was verified that the waters with higher concentrations of organic matter $A_{2}$ and $A_{3}$ (Table 2) promoted higher mean contents of $P$ (Table 3). A significant effect was verified for the irrigation depths when using the $\mathrm{A}_{4}$ water, verifying a higher concentration of $P$ in the $L_{2}$ depth, allowing to infer that the higher soil moisture, as a consequence of the higher wet area, allowed a greater absorption of $\mathrm{P}$, and that it is necessary to employ a complementary phosphate fertilization when irrigating with this type of water, especially when using the $L_{1}$ irrigation depth.

In average, the leaf contents of $P$ in the treatments irrigated with domestic effluents are in accordance with the critical levels of the 
sufficiency range reported by Nascimento et al. (2013), which corresponded to 2.9 and $4.5 \mathrm{~g} \mathrm{~kg}^{-1}$. As to the $S$, when irrigating with the $L_{1}$ depth, the highest contents were verified when using the $A_{2}$ and $A_{3}$ waters, being justified by the higher concentration of sulfates in these types of water and the lower contents with the $A_{4}$, with the latter levels being also inferior to the levels determined by Malavolta et al. (1997) and Zobiole et al. (2010), which are between 5-7 $\mathrm{g} \mathrm{kg}^{-1}$. In the unfolding of the interaction between the water sources and the irrigation depths, a significant effect was only verified for the $\mathrm{A}_{3}$ water, corresponding to an increase of $24 \%$ in the content of $S$ when using the $L_{1}$ irrigation depth (Table 3).

Using orthogonal contrasts, it was observed that the plants irrigated with the $A_{2}$ waters presented highest mean concentrations of $N\left(24.31 \mathrm{~g} \mathrm{~kg}^{-1}\right)$, differing with regard to the remaining water sources, with an increase of $38 \%$

Table 4. F test for the orthogonal contrasts and content (means and standard error) of nutrients in sunflower leaves

\begin{tabular}{|c|c|c|c|c|}
\hline Contrasts & $\mathrm{N}$ & \multicolumn{2}{|c|}{ F test } & $\mathrm{Mg}$ \\
\hline $1-A_{1} v S A_{2}$ & $8.49^{* *}$ & $0.61^{\text {n.s. }}$ & $0.03^{\text {n.s. }}$ & $0.064^{\text {n.s. }}$ \\
\hline $2-A_{1}$ vs $A_{3}$ & $1.60^{\text {n.s. }}$ & $0.94^{\text {n.s. }}$ & $1.15^{\text {n.s. }}$ & $0.001^{\text {n.s. }}$ \\
\hline $3-A_{1}$ vs $A_{4}$ & $1.98^{\text {n.s. }}$ & $8.66^{* *}$ & $7.02 *$ & $13.58^{* *}$ \\
\hline $4-A_{2} v s A_{3}$ & $17.48^{* *}$ & $0.03^{\text {n.s. }}$ & $1.55^{\text {n.s. }}$ & $0.05^{\text {n.s. }}$ \\
\hline $5-A_{2}$ vs $A_{1}+A_{3}$ & $16.78^{* *}$ & $0.12^{\text {n.s. }}$ & $0.67^{\text {n.s. }}$ & $0.075^{\text {n.s. }}$ \\
\hline $6-A_{4} v s A_{1}+A_{2}+A_{3}$ & $5.74^{*}$ & $18.65^{* *}$ & $13.05^{* *}$ & $21.42^{* *}$ \\
\hline Water sources & \multicolumn{4}{|c|}{ Means and standard error $\left(\mathrm{g} \mathrm{kg}^{-1}\right)$} \\
\hline$A_{1}$ & $18.81 \pm 1.24$ & $57.77 \pm 7.23$ & $23.70 \pm 2.02$ & $12.38 \pm 0.67$ \\
\hline $\mathrm{A}_{2}$ & $24.31 \pm 1.43$ & $63.25 \pm 5.39$ & $23.21 \pm 2.48$ & $12.63 \pm 0.59$ \\
\hline $\mathrm{A}_{3}$ & $16.42 \pm 1.27$ & $64.55 \pm 3.43$ & $26.69 \pm 2.72$ & $12.41 \pm 0.94$ \\
\hline $\mathrm{A}_{4}$ & $16.15 \pm 1.36$ & $37.17 \pm 3.44$ & $16.30 \pm 1.26$ & $8.81 \pm 0.37$ \\
\hline
\end{tabular}

$\mathrm{kg} \mathrm{ha}^{-1}$ when irrigated with the $\mathrm{A}_{2}$ water, which provided mean $\mathrm{N}$ contents in the shoot part ranging from 16.1 to $24.3 \mathrm{~g} \mathrm{~kg}^{-1}$, respectively. In studies with the sunflower crop, with plants collected in the same phenological stage as those of the present cultivation, Zobiole et al. (2010) observed $\mathrm{N}$ concentrations in the leaves of $15.5 \mathrm{~g} \mathrm{~kg}^{-1}$ associated to the achene yield of $3,344 \mathrm{~kg} \mathrm{ha}^{-1}$, thus allowing to infer that the $\mathrm{N}$ concentrations in the plant tissue were adequate.

Experimental studies suggest that $\mathrm{N}$ doses from 40 to $50 \mathrm{~kg} \mathrm{ha}^{-1}$ are enough to obtain $90 \%$ of the maximum relative sunflower yield (Biscaro et al., 2008). Therefore, the use of effluents might have provided $\mathrm{N}$ beyond the dose demanded in relation to the $A_{1}$ and $A_{3}$ treatments (contrasts 5 of Table 4), attributed to the better nutritional balance of this solution, since it obtained the highest achene yield $\left(3,644.4 \mathrm{~kg} \mathrm{ha}^{-1}\right)$ even in the lower concentration of $\mathrm{N}$.

The use of $\mathrm{A}_{2}$ waters provided higher contents of $\mathrm{N}$ in the sunflower leaves, verifying a significant effect in all contrasts with these waters (Table 4).

The $\mathrm{A}_{4}$ waters provided $\mathrm{N}$ contents equivalent to the $A_{1}$ and $A_{3}$ (contrast 3 - Table 4), representing, in this case, a false positive associated to the concentration effect of this nutrient in the leaves, since these plants were underdeveloped. Concentration effects were also verified by Lavado (2006) and by Nascimento et al. (2013) when they worked with sewage sludge stabilized by different processes.

The average achene yield ranged from $1,677.5 \mathrm{~kg} \mathrm{ha}^{-1}$ with the use of $A_{4}$ waters to 3,644.4 by the crop, resulting in a possible yield reduction, since a range from 234.5 to $337.3 \mathrm{~kg}$ of $\mathrm{N} \mathrm{ha}^{-1}$ was applied via irrigation with effluents.

For the contents of K, Ca, Mg and S, there was no significant effect between the treatments irrigated with effluents. However, there was a significant effect in the contrasts related to the treatments irrigated with supply water (contrasts 3 and 6) (Table 4), suggesting that the irrigation with treated domestic sewage provides a significant amount of macronutrients that might be used by the plants, with studies on the dilution adjustments being necessary to equalize the applied irrigation depth and the nutritional supply to the hydric and nutritional needs of the 
crop, aiming to optimize the yields of the crops according with each type of effluent. Similar results were verified by Lobo \& Grassi Filho (2007), Damasceno et al. (2011) and Pereira et al. (2011). In the capitula, significant effects $(p<0.01)$ of the water types in the concentrations of $\mathrm{P}, \mathrm{Ca}$ and $S$ were observed. For the $P$, it was verified that the treatments irrigated with domestic effluents presented concentrations above those irrigated with supply water, especially the $A_{2}$ and $\mathrm{A}_{3}$ effluents (Table 5). For the $\mathrm{Ca}$, higher concentrations were verified using the $A_{1}$ water Table 5. F test for the orthogonal contrasts and content (m
(UASB) $\left(6.01 \mathrm{~g} \mathrm{~kg}^{-1}\right)$, corresponding to the one that presented the highest supply of this nutrient (Table 2). The contents of $S$ in the capitula were also influenced by the types of sewage treatment (Table 5).

In the achenes, the effect of the interaction between water types and irrigation depths was verified for the contents of $K(p<0.05)$ and $S(p<0.01)$, and an isolate effect of the water types for $\mathrm{P}, \mathrm{Mg}(\mathrm{p}<0.01)$, and $\mathrm{Ca}(\mathrm{p}<0.05)$.

For the content of $\mathrm{K}$, it was verified that from the unfolding of the water types within (means and standard error) of nutrients in capitulum

\begin{tabular}{|c|c|c|c|c|}
\hline Contrasts & $P$ & K & $\mathrm{Ca}$ & S \\
\hline $1-A_{1} \vee S A_{2}$ & $3.63^{\text {n.s. }}$ & $0.11^{\text {n.s. }}$ & $23.59 * *$ & $5.81^{\text {n.s. }}$ \\
\hline $2-A_{1} v s A_{3}$ & $3.36^{\text {n.s. }}$ & $0.16^{\text {n.s. }}$ & $4.72 *$ & $0.07^{\text {n.s. }}$ \\
\hline $3-A_{1} \vee s A_{4}$ & $8.57^{* *}$ & $2.61^{\text {n.s. }}$ & $7.25^{*}$ & $32.50 * *$ \\
\hline $4-\mathrm{A}_{2}$ VS $\mathrm{A}_{3}$ & $0.005^{\text {n.s. }}$ & $0.004^{\text {n.s. }}$ & $7.21^{*}$ & $4.64^{*}$ \\
\hline $5-A_{2} v s A_{1}+A_{3}$ & $1.31^{\text {n.s. }}$ & $0.025^{\text {n.s. }}$ & $18.96^{* *}$ & $6.95^{*}$ \\
\hline 6- $A_{4} v s A_{1}+A_{2}+A_{3}$ & $26.13^{* *}$ & $5.17^{*}$ & $0.18^{\text {n.s. }}$ & $65.15^{* *}$ \\
\hline Water sources & \multicolumn{4}{|c|}{ Means and standard error $\left(\mathrm{g} \mathrm{kg}^{-1}\right)$} \\
\hline $\mathrm{A}_{1}$ & $5.42 \pm 0.41$ & $73.88 \pm 5.04$ & $6.01 \pm 0.37$ & $8.14 \pm 0.37$ \\
\hline $\mathrm{A}_{2}$ & $6.87 \pm 0.58$ & $75.81 \pm 3.41$ & $3.43 \pm 0.48$ & $9.38 \pm 0.25$ \\
\hline $\mathrm{A}_{3}$ & $6.82 \pm 0.70$ & $76.17 \pm 3.82$ & $4.85 \pm 0.31$ & $8.27 \pm 0.26$ \\
\hline $\mathrm{A}_{4}$ & $3.18 \pm 0.37$ & $64.57 \pm 3.98$ & $4.58 \pm 0.54$ & $5.22 \pm 0.54$ \\
\hline
\end{tabular}

the irrigation depths there was a significant difference only for the $\mathrm{A}_{1}$ water, thus verifying the highest content of the nutrient with the use of the $\mathrm{L}_{2}$ depth (Table 6). For the $\mathrm{L}_{1}$ depth, higher levels of $K$ were verified in the treatments irrigated with treated domestic sewage $\left(A_{1}, A_{2}\right.$ and $\left.A_{3}\right)$, whereas in the $L_{2}$ depth, higher $K$ contents in the achenes were verified when irrigating with $A_{1}$ waters from the UASB reactor $\left(A_{1}\right)$ (Table 6).

It was expected that the plots irrigated with the $\mathrm{A}_{3}$ water presented higher concentrations of $K$ as a consequence of the greater supply of this nutrient in the referred effluent; however, it is worth noting that the evaluation must also be made in the aspect of the extraction of the nutrients by the respective plant parts; in this manner, according to Dantas et al (2016), the more demanding organs with regard to $K$ in the sunflower crop are the leaves and capitula, followed by the achenes, with 1.52, 1.18 and $0.37 \mathrm{~g} \mathrm{plant}^{-1}$ respectively, referring to the higher absorptions of this nutrient by leaves and capitulum, what actually occurred in the present study.

For the content of $S$, irrigating with $L_{1}$ depth, higher values were observed with the

Table 6. Contents (mean and standard error) of $\mathrm{K}$ and $\mathrm{S}$ in the achenes of the irrigated sunflower $\mathrm{Cv}$. $\mathrm{H} 250 \mathrm{Os}$ a function of the water types and irrigation depths

\begin{tabular}{crlrlrlll}
\hline Water sources & \multicolumn{3}{c}{$\mathrm{K}\left(\mathrm{g} \mathrm{kg}^{-1}\right)$} & \multicolumn{3}{c}{$\mathrm{S}\left(\mathrm{g} \mathrm{kg}^{-1}\right)$} \\
\hline $\mathrm{A}_{1}$ & $9.8 \pm 0.21$ & $\mathrm{aB}$ & $12.3 \pm 0.24$ & $\mathrm{aA}$ & $0.8 \pm 0.29$ & $\mathrm{bA}$ & $1.7 \pm 0.34$ & $\mathrm{bA}$ \\
$\mathrm{A}_{2}$ & $10.2 \pm 0.74$ & $\mathrm{aA}$ & $10.4 \pm 0.21$ & $\mathrm{bA}$ & $2.3 \pm 0.07$ & $\mathrm{aA}$ & $1.1 \pm 0.20$ & $\mathrm{bB}$ \\
$\mathrm{A}_{3}$ & $9.9 \pm 0.31$ & $\mathrm{aA}$ & $10.3 \pm 0.49$ & $\mathrm{bA}$ & $1.9 \pm 0.36$ & $\mathrm{aA}$ & $1.8 \pm 0.52$ & $\mathrm{bA}$ \\
$\mathrm{A}_{4}$ & $9.2 \pm 0.14$ & $\mathrm{bA}$ & $9.9 \pm 0.44$ & $\mathrm{bA}$ & $1.1 \pm 0.21$ & $\mathrm{bB}$ & $2.9 \pm 0.33$ & $\mathrm{aA}$ \\
\hline
\end{tabular}

water types $A_{2}$ and $A_{3}$, whereas with the $L_{2}$ depth, higher concentrations of $S$ were verified with the water type $\mathrm{A}_{4}$
A further significant difference was verified in the $S$ content in the achenes, as a function of the irrigation depth for the treatments 
$A_{2}$ and $A_{4}$; these results are in accordance with those obtained by Pereira et al (2011), who verified that the application of irrigation depths above the ETC, when of the use of treated domestic sewages, might cause a nutritional unbalance by the accumulation of $\mathrm{SO}_{4}^{-2}$ in solution as a consequence of the addition of $\mathrm{SO}_{4}^{-2}$ provided by domestic sewages and by the increase in soil $\mathrm{pH}$, what might increase the sulfate desorption of oxyhydroxides of $\mathrm{Fe}$ and $\mathrm{Al}$, thus increasing the concentration of $\mathrm{SO}_{4}^{2-}$ in the soil solution.

Higher contents were observed when use the $A_{2}$ water associated with the $L_{1}$ depth, whereas for the $A_{4}$ water, higher contents were observed when irrigating with the $L_{2}$ depth (Table 6).

The utilization of domestic effluents provided an average increase of $23.22 \%$ in the content of $P$ in relation to the irrigation with $A_{4}$ water, suggesting that the $P$ of the effluents supplied the crop demand. Among the treatments with domestic effluents, it was observed that those from the $A_{2}$ treatment provided the highest contents of $\mathrm{P}$, probably due to the better ionic balance of the solution as a consequence of the lower amount of calcium in these effluents, leading to a lower precipitation of $P$ and a higher availability of this element for the crop (Table 7).

It is worth noting that $P$ deficiency might reduce both cellular respiration and photosynthesis, interfering in the synthesis of nucleic acids and proteins, and inducing the accumulation of soluble nitrogen compounds in the tissue. In studies in the sunflower crop, Prado \& Leal (2006) observed that the deficiency of $P$ affected the attributes that reflect the vegetative growth, such as the decrease in the number of leaves, plant height, stem diameter and leaf area.

Higher concentrations of $\mathrm{Ca}$ were verified in the plots irrigated with supply water

Table 7. F test for the orthogonal contrasts and contents (means and standard error) of nutrients in the achenes

\begin{tabular}{|c|c|c|c|c|c|}
\hline Contrasts & $P$ & K & $\begin{array}{c}\text { Ca } \\
\text { F test }\end{array}$ & Mg & S \\
\hline $1-A_{1} V S A_{2}$ & $2.67^{\text {n.s. }}$ & $4.17^{\text {n.s. }}$ & $0.36^{\text {n.s. }}$ & $0.85^{\text {n.s. }}$ & $2.54^{\text {n.s. }}$ \\
\hline $2-\mathrm{A}_{1}$ vs $\mathrm{A}_{3}$ & $2.46^{\text {n.s. }}$ & $6.21^{*}$ & $5.32^{*}$ & $1.17^{\text {n.s. }}$ & $3.64^{\text {n.s. }}$ \\
\hline $3-\mathrm{A}_{1}$ vs $\mathrm{A}_{4}$ & $14.32 * *$ & $15.91^{* *}$ & $8.89 * *$ & $5.77^{\text {n.s. }}$ & $5.27^{*}$ \\
\hline $4-\mathrm{A}_{2} \vee s \mathrm{~A}_{3}$ & $10.27^{* *}$ & $0.21^{\text {n.s. }}$ & $2.92^{\text {n.s. }}$ & $0.02^{\text {n.s. }}$ & $0.09^{\text {n.s. }}$ \\
\hline $5-A_{2}$ Vs $A_{1}+A_{3}$ & $7.81 *$ & $0.85^{\text {n.s. }}$ & $0.41^{\text {n.s. }}$ & $0.19^{\text {n.s. }}$ & $0.55^{\text {n.s. }}$ \\
\hline $6-A_{4}$ Vs $A_{1}+A_{2}+A_{3}$ & $21.72 * *$ & $9.21^{* *}$ & $6.08^{*}$ & $14.13^{* *}$ & $1.91^{\text {n.s. }}$ \\
\hline Water sources & & \multicolumn{4}{|c|}{ Means and standard error $\left(\mathrm{g} \mathrm{kg}^{-1}\right)$} \\
\hline$A_{1}$ & $16,92 \pm 0,65$ & $11.06 \pm 0.50$ & $10.23 \pm 1.64$ & $6.57 \pm 0.13$ & $1.22 \pm 0.27$ \\
\hline $\mathrm{A}_{2}$ & $18.27 \pm 0.57$ & $10.29 \pm 0.36$ & $11.68 \pm 2.17$ & $7.07 \pm 0.56$ & $1.74 \pm 0.23$ \\
\hline $\mathrm{A}_{3}$ & $15.62 \pm 0.44$ & $10.13 \pm 0.28$ & $15.80 \pm 1.44$ & $7.15 \pm 0.37$ & $1.85 \pm 0.29$ \\
\hline $\mathrm{A}_{4}$ & $13.78 \pm 0.54$ & $9.56 \pm 0.25$ & $17.43 \pm 1.26$ & $5.27 \pm 0.37$ & $1.97 \pm 0.38$ \\
\hline
\end{tabular}

$\left(A_{4}\right)$, probably due to the lower development of the plants, characterizing a concentration effect of the nutrient, justifying its accumulation in the reserve organs (achenes). The use of treated domestic effluents influences in the concentration of $\mathrm{Mg}$ of the achenes, with an increase of $31.5 \%$ being verified in relation to the treatment irrigated with supply water.

\section{Conclusions}

The sunflower nutritional status was influenced by the types of treatments for the domestic sewage, mainly regarding $\mathrm{N}, \mathrm{Ca}$ and $\mathrm{S}$, as well as by the irrigation depth for the nutrients $P, K$ and $S$;
The sunflower crop presented a better nutritional balance when irrigated with treated domestic effluents;

With the irrigation with supply water, it is necessary to provide a nutritional supply of $P$ and $S$, primarily, especially when irrigating with an irrigation depth equivalent to the crop evapotranspiration.

\section{Acknowledgments}

The authors thank the National Council of Scientific and Technological Development (CNPq) for the financial support for this research.

\section{References}

Albuquerque, F.S., Silva, E.F.F., Albuquerque 
Filho, J.A.C., Nune, M.F.F.N., 2011 . Crescimento e rendimento de pimentão fertigado sob diferentes lâminas de irrigação e doses de potássio. Revista Brasileira Engenharia Agrícola Ambiental 15: 686 - 694.

Allen, R.G., Pereira, I.S., Raes, D., Smith. 2006. Evapotranspiracion del cultivo: guias para la determinación de los requerimientos de agua de los cultivos. FAO. Estudio Riego e Drenaje Paper, 56. Roma. 298p.

Alvarez V. V.H., Novais, R.F., Barros, N.F., Cantarutti, R.B., Lopes, A.S. 1999. Interpretação dos resultados das análises de solos. In: Ribeiro, A.C., Guimarães, P.T.G., Alvarez V., V.H., eds. Recomendação para o uso de corretivos e fertilizantes em Minas Gerais. 5a aproximação. Viçosa, MG, CFSEMG, 359p.

APHA, AWWA, WEF. 2005. Standard methods for the examination of water and wastewater. $21^{\text {st }}$ ed. Washington, USA. 1268p.

Bezerra Neto, E., Barreto, L.P. 2011. Análises químicas e bioquímicas em plantas. Recife: UFRPE, Editora Universitária da UFRPE, 267p.

Bezerra, B.G., Fideles Filho, J. 2009. Análise de crescimento da cultura do algodoeiro irrigada com águas residuárias. Revista Ciência Agronômica, 40: 339-345.

Biscaro, G.A., Machado, J.R., Tosta, M.S., Mendonça, V., Soratto, R.P., Carvalho, L.A. 2008. Adubação nitrogenada em cobertura no girassol irrigado nas condições de CassilândiaMS. Ciência e Agrotecnologia 32: 366-373.

Castamann, A., Escosteguyll, P.A.V., BerresllI, D., Zanella, S. 2012. Diagnosis and recommendation integrated system (DRIS) of soy bean seed oil content. Revista Brasileira de Ciência do Solo 36: 1820-1827.

Damasceno, L.M.O., Andrade Júnior, S., Gheyi, H.R., Dias, N.S., Silva, C.O. 2011. Composição nutricional foliar da gérbera irrigada com efluente doméstico tratado. Revista Caatinga 24: 21-128.

Dantas, M.S.M., Rolim, M.M.R., Pedrosa, E.M.R., Bezerra Neto, E., Silva, G.F, Silva, E.F.F. 2016. Accumulation of macronutrients in different parts of sunflower fertilized with cassava wastewater. Revista Brasileira de Engenharia Agrícola e Ambiental. 20:630-636.

Deon, M.D., Gomes, T.M., Melfi, A.J., Montes, C.R., Silva, E. 2010. Produtividade e qualidade da cana-de-açúcar irrigada com efluente de esgoto de estação de tratamento de esgoto. Pesquisa Agropecuária Brasileira 45: $1149-1156$.

Freitas, C.A.S., Silva, A.R.A., Bezerra, F.M.L.,
Andrade, R.R., Mota, F.S.B., Aquino, B.F. 2012. Crescimento da cultura do girassol irrigado com diferentes tipos de água e adubação nitrogenada. Revista Brasileira de Engenharia Agrícola e Ambiental 16: 1031-1039.

Friedman, H., Bernstein, N., Bruner, M., Rot, I., Bennoon, Z., Zuriel, A., Zuriel, R., Finkelstein, S., Umiel, N., Hagilandi, A. 2007. Application of secondarytreated effluents for cultivation of sunflower (Helianthus annuus L.) and celosia (Celosia argentea L.) as cut flowers. Scientia Horticulturae 115: 62-69.

Hue, N.V. 1991. Effects of organic acids/anions on phosphorus sorption and phyto availability in soils with different mineralogies. Soil Science 152: 463-471.

Lavado, R. 2006. Effects of sewage-sludge application on soils and sunflower yield: quality and toxic element accumulation. Journal of Plant Nutrition, 29: 975-984.

Lobo, T.F.; Grassi Filho, H. 2007. Níveis de lodo de esgoto na produtividade do girassol. Revista de la Ciência del Suelo y Nutrición Vegetal 7: 16-25.

Malavolta, E., Vitti, G.C., Oliveira, S.A. 1997. Avaliação do estado nutricional de plantas: Princípios e aplicações. Piracicaba, Potafos, Brasil, 319p.

Nascimento, A.L., Sampaio, R.A., Fernandes, L.A., Zuba Junio, G.R., Carneiro, J.P., Rodrigues, M.N., Albuquerque, H.C. 2013. Yield and nutrition of sunflower fertilized with sewage sludge stabilized by different processes. Revista Ceres 60: 683-689.

Pereira, B.F.F., He, Z.L., Silva, M.S., Herpin, U., Nogueira, S.F., Montes, C.R., Melfi, A.J. 2011. Reclaimed wastewater: Impact on soil-plant system under tropical conditions. Journal of Hazardous Materials, 192: p.54-61.

Prado, R.M., Leal, R.M. 2006. Desordens nutricionais por deficiência em girassol var. Catissol-01. Pesquisa Agropecuária Tropical, 36 (3): 187-193.

Santos Junior, J.A., Gheyi, H.R., Dias, N.S., Soares, F.A.L., Nobre, R.G. 2011. Doses de boro e água residuária na produção do girassol. Revista Ciência Agronômica 42: 857-864.

Singh, S.P.; Prerna, P. 2009. Review of recent advances in anaerobic packed bed biogas reactors. Renewable and Sustainable Energy Reviews 13: 1569-1575.

Zobiole, L.H.S., Castro, C.; Oliveira, F.A., Oliveira Junior, A. 2010. Marcha de absorção de macronutrientes na cultura do girassol. Revista Brasileira de Ciência do Solo 34: 425-433. 